\title{
Effect of Temperature Treatments on Seed Germination and Seedling Growth of Jute Mallow (Corchorus olitorius)
}

\author{
Abigail Larnyo*, Promise Joshua Atitsogbui
}

\author{
*West Africa Centre for Crop Improvement, College of Basic and Applied Sciences, University of Ghana, PMB LG 30, Noguchie Link, Accra, \\ Ghana. \\ *Corresponding Author
}

Received: 02 Nov 2020; Received in revised form: 13 Dec 2020; Accepted: 25 Dec 2020; Available online: 30 Dec 2020

(C)2020 The Author(s). Published by Infogain Publication. This is an open access article under the CC BY license

(https://creativecommons.org/licenses/by/4.0/).

\begin{abstract}
Jute mallow (Corchorus olitorius) is one of the common green leafy vegetables used widely throughout Ghana. Jute mallow is cultivated by seeds and the demand for the crop is year-round. Despite the high demand, its efficient production is marred by poor seed germination. Thus, this study seeks to determine the effect of pre-chill, dry and wet heat on germination, seedling emergence and seedling vigor of jute mallow.

Results revealed that hot water at $70^{\circ} \mathrm{C}$ with combination of $70^{\circ} \mathrm{C}$ oven heat for thirty (30) minutes produced the best germination, emergence and seedling vigour. The effect of hot water at $70^{\circ} \mathrm{C}$ only was also significantly higher than other treatments.

Jute mallow farmers who produce on small scale could use hot water at $70^{\circ} \mathrm{C}$ to treat seeds before sowing. Large scale producers, however, could use a combination of hot water at $70^{\circ} \mathrm{C}$ and oven heat at $70^{\circ} \mathrm{C}$ to treat seeds before sowing.
\end{abstract}

Keywords - temperature treatment, seed germination, seedling vigour, jute mallow, Corchorus olitorius.

\section{INTRODUCTION}

Corchorus olitorius, also known as Jew or jute mallow or bush okra is one of the popular tropical leafy vegetables in Africa, Asia and some part of the Middle East (Olabode and Sangodele, 2014). Studies have shown that jute mallow is considered as a vegetable in most parts of Africa and is widely consumed among rural communities (Velempini et al., 2003). It is an annual crop popularly known in southern Ghana as "Ademe" and northern Ghana as "Ayoyo". It plays very significant role in household nutrition and it is very affordable. It is used to prepare sauce and soup delicacies and its mucilaginous property when cooked facilitate swallowing of solid foods. Hence most parents introduce it to babies who are learning to eat solid foods for the first time. In Ghana, jute mallow is eaten with starchy foods such as "banku", "akple" and "tuo-zafi" due to its ability to enhance swallowing.

Jute mallow was usually found in the wild but recently the health consciousness of many Ghanaians to eat healthy has increased the demand for its consumption hence making it necessary for farmers to deliberately grow them on commercial scale. However, the hard seed coat of jute mallow seeds cause physical dormancy hence, its delay in seed germination (Tareq et al., 2015). Attempts at breaking seed dormancy in jute mallow include the use of heat under constant temperatures (Wahab, 2011), seed scarification (Emongor et al 2004) and use of

chemicals such as sulphuric acid (M. Palada and Chang, 2003). Palada and Chang (2003), reported that when jute mallow seeds are steeped in boiled water, seed germination 
and seedling emergence are enhanced. These studies produced germination percentage between $40 \%-80 \%$.

Mechanical scarification usually makes the surface of seeds permeable to water but reduces seedling vigor. Apart from reducing seedling vigor, the size(small) of the seed makes it difficult to carry out mechanical scarification on jute mallow seeds (Velempini et al., 2003). Some of these treatments involve chemicals which do not only overburden small scale farmers with high production cost but these chemicals are not easily accessible. It is important to exploit feasible and effective methods that can be used by small scale farmers as well as commercial farmers to enhance germination and seedling vigor. Application of heat may be easier than earlier attempts that are more difficult to apply especially by small scale farmers. Thus, this study seeks to assess seed quality of jute mallow in terms of health, purity and viability while assessing rate of seed germination and seedling vigor, following different methods of breaking dormancy using heat treatments.

\section{MATERIALS AND METHODS}

The experiment was conducted at the laboratory of Ghana Seed Inspection Division (GSID) located at Pokuase, Accra and the Pathology Laboratory of Crop Science Department, University of Ghana. Jute mallow seeds used for the study were farmer saved seeds and were purchased from seed shop in Accra.

Seed viability test was conducted by using floatation method (www.agrifarming.in). In this process, seeds were poured into beaker containing water and allowed to settle for 20 minutes. Viable seeds are usually heavier than unviable seeds hence they settled at the bottom of the glass beaker while the lighter seeds with other impurities floated on the water.

The purity test was conducted according to the rule of International Seed Testing Association (ISTA, 2017). The aim of the purity test was to determine the percentage composition by weight of the seed being used. Two hundred grams $(200 \mathrm{~g})$ of seeds were weighed and mixed thoroughly by hand. The seeds were poured onto the purity working board with reflected light to enhance vision; this was done with about 150 seeds at a time. Magnifiers were used to aid the separation of seeds into various components by magnifying the seeds and other components. The components were pure seeds, other seeds and inert matter. Pure seeds were seeds with all the features of jute mallow.
Other seeds were defined as seeds of other plants that may be present. Inert matter was the materials that were neither pure seeds nor other seeds.

Purity percentage was calculated by dividing the weight in grams of pure seeds by the total seed weight and multiplied by 100 as shown in the equation 1 below:

$$
P=\left(\frac{P_{w s}}{T_{w s}}\right) x 100 \% \quad \text { Equation } 1
$$

Where purity percentage is denoted by $\mathrm{P}$, weight of pure seeds as $P_{w s}$ and total seed weight denoted by $T_{w s}$.

\section{Seed Moisture Test}

Seed moisture test was done by weighing one hundred grams $(100 \mathrm{~g})$ of seeds on a weighing scale. The seeds were poured into a digital moisture meter and calibrated to shallot seed. The calibration did not have jute mallow seeds on the machine so shallot was used since it has similar seed size.

To conduct health test on the seeds, ten (10) glass petri dishes were sterilized in a hot oven sterilizer at $175^{\circ} \mathrm{C}$ for 90 minutes. Ten milliliters $(10 \mathrm{ml})$ of Potato Dextrose Agar (PDA) media was poured into each sterilized petri dish. Ten (10) seeds were placed in each petri dish and covered. This was replicated ten (10) times, making a total of hundred (100) seeds. The petri dishes were labeled and incubated for five days to observe the presence of pathogens on the seed surface.

Two grams $(2 \mathrm{~g})$ of seeds were placed in a conical flask and $1 \%$ sodium hypochlorite was poured into the flask for sixty (60) seconds to sterilize the surface of the seed.

The contents in the flask were sieved and the seeds were poured onto a tissue paper to absorb the remaining moisture on it. Ten (10) glass petri dishes were sterilized in a hot oven sterilizer at $175^{\circ} \mathrm{C}$ for 90 minutes. Ten milliliters $(10 \mathrm{ml})$ of PDA media was poured into each sterilized petri dish. Ten (10) seeds were placed in each petri dish and covered. This was replicated ten (10) times, making a total of hundred (100) seeds. The petri dishes were labeled and incubated for five days to observe the presence of pathogens within the seed.

\section{Seed Treatments to Break Dormancy}

Seeds were subjected to Ten (10) temperature treatments $(\mathrm{T})$ and assessed for germination, emergence and seedling vigor as shown in table 1. A control, where seeds 
were sown without temperature treatment was included in the study. For oven treatments, the oven was pre-heated.

Table 1: Seed Treatments Evaluated for Ability to Break Dormancy

\begin{tabular}{|c|c|}
\hline Treatment & Procedure \\
\hline Treatment 1 & Soak seeds for 15 hours at $21^{\circ} \mathrm{C}$ \\
\hline Treatment 2 & $\begin{array}{l}\text { Soak seeds for } 15 \text { hours at } 21^{\circ} \mathrm{C} \text {, followed } \\
\text { by heating at } 70^{\circ} \mathrm{C} \text { for } 30 \text { minutes }\end{array}$ \\
\hline Treatment 3 & Dip seed in hot water at $70^{\circ} \mathrm{C}$ for 5 minutes \\
\hline Treatment 4 & $\begin{array}{l}\text { Dip seeds in hot water at } 70^{\circ} \mathrm{C} \text { for } 5 \text { minutes, } \\
\text { followed by heating at } 70^{\circ} \mathrm{C} \text { for } 30 \text { minutes }\end{array}$ \\
\hline Treatment 5 & Pre-chill seeds at $5^{\circ} \mathrm{C}$ for 24 hours \\
\hline Treatment 6 & $\begin{array}{l}\text { Pre-chill seeds at } 5^{\circ} \mathrm{C} \text { for } 24 \text { hours, followed } \\
\text { by heating at } 70^{\circ} \mathrm{C} \text { for } 30 \text { minutes }\end{array}$ \\
\hline Treatment 7 & Oven heat seeds at $70^{\circ} \mathrm{C}$ for 30 minutes \\
\hline Treatment 8 & Oven heat seeds at $80^{\circ} \mathrm{C}$ for 30 minutes \\
\hline Treatment 9 & Oven heat seeds at $90^{\circ} \mathrm{C}$ for 30 minutes \\
\hline $\begin{array}{l}\text { Treatment } 10 \\
\quad \text { (control) }\end{array}$ & Sowing seeds directly \\
\hline
\end{tabular}

Germination Test

Germination was done by using the top of paper method. Hundred seeds from each treatment were sown on filter paper. This procedure was replicated four (4) times. Germination counts started on the third day after planting and continued for a total period of 14 days when most of the seeds had germinated. Radicle (root) emergence was used as the criterion for germination (Denton et al., 2013). The percentage germination was calculated by dividing the total number of seeds that germinated over the number of seeds sown and multiplied by hundred (Denton et al., 2013) as shown in equation 2 below.

$$
G P(\%)=\frac{T_{s g}}{T_{s s n}} \times 100 \quad \text { Equation } 2
$$

where germination percentage is denoted by $G P$, total number of seeds germinated is denoted by $T_{s g}$, and total number of seeds sown denoted by $T_{s s n}$.

\section{Seedling Emergence and Seedling Vigor Index}

The experiment was a complete randomized design. One hundred seeds were taken from each treatment and sown in a germination tray which was filled with sand to about $3 \mathrm{~cm}$ thick. Each treatment had three (3) replications.
The set up was irrigated lightly every day to ensure adequate water supply for germination and to prevent the seed from drifting away from the planted rows.

The numbers of seedling emergence were recorded on daily basis, starting from the third day after sowing until 14 days after sowing. Seedling was scored as emerged when the cotyledons break through the soil surface and the percentage seedling emergence was calculated by dividing the total number of seedlings that emerged by the number of seeds sown and multiplied by hundred.

On the 14th day, measurements of seedling length were carried out on 10 randomly selected seedlings from each replicated tray (Denton et al., 2013). The seedling vigor index was calculated by multiplying the seedling length by percentage seedling emergence (Denton et al., 2013).

$$
E P(\%)=\frac{T_{s e}}{T_{s s n}} \times 100 \text { Equation } 3
$$

where emergence percentage (\%) is denoted by $E P$, total number of seeds emerged denoted by $T_{\text {se }}$, and total number of seeds sown denoted by $T_{s s n}$

\section{RESULTS}

\section{Seed Quality}

The seed quality tests revealed that ninety two percent $(92 \%)$ of the jute mallow seeds were viable and eighty seven percent $(87 \%)$ pure. Seed health test within the seed revealed no contaminants however test on the seed surface showed that seeds carried 10\% fungal pathogens and $5 \%$ bacterial pathogens refer to table 2 .

Table 2: Results of Seed Quality Tests

\begin{tabular}{cc}
\hline Seed Quality test & Results in percentage (\%) \\
\hline Seed viability & 92 \\
Seed moisture & 11 \\
Seed purity & 87 \\
Seed health (within seed) & 100 \\
Seed health (seed surface) & 85 \\
\hline
\end{tabular}

\section{Effect of Treatments on Percentage Germination and Emergence}

Seeds that were treated with hot water and oven heat combination resulted in the highest percentage of 
germination of $92 \%$, as well as the highest emergence of $87 \%$ (see table 3 ).

The untreated seeds resulted in the lowest percentage germination $(2.5 \%)$ and there was no seedling emergence.

Table 2: Effect of temperature treatments on percentage germination and emergence

\begin{tabular}{|c|c|c|}
\hline Treatments & $\begin{array}{c}\text { Percent } \\
(\%) \\
\text { Germinati } \\
\quad \text { on }\end{array}$ & $\begin{array}{c}\text { Percent }(\%) \\
\text { Emergence }\end{array}$ \\
\hline $\begin{array}{c}\text { Soak seeds in water at } 21^{\circ} \mathrm{C} \text { for } 15 \\
\text { hours }\end{array}$ & 5 & 1 \\
\hline $\begin{array}{c}\text { Soaking in water at } 21^{\circ} \mathrm{C}+\text { oven } \\
\text { heat }\end{array}$ & 26 & 19 \\
\hline Hot water & 77 & 61 \\
\hline Hot water + oven heat & 92 & 86 \\
\hline Pre-chill seeds at $5^{\circ} \mathrm{C}$ for 24 hours & 8 & 7 \\
\hline Pre chilling+ oven heat & 49 & 38 \\
\hline $\begin{array}{c}\text { Oven heat seeds at } 70^{\circ} \mathrm{C} \text { for } 30 \\
\text { minutes }\end{array}$ & 38 & 33 \\
\hline $\begin{array}{c}\text { Oven heat seeds at } 80^{\circ} \mathrm{C} \text { for } 30 \\
\text { minutes }\end{array}$ & 42 & 40 \\
\hline $\begin{array}{l}\text { Oven heat seeds at } 90^{\circ} \mathrm{C} \text { for } 30 \\
\text { minutes }\end{array}$ & 48 & 41 \\
\hline Control & 2.5 & 0 \\
\hline
\end{tabular}

Table 4: Effect of temperature treatment on seedling length (cm) and seedling vigor of jute mallow seeds

\begin{tabular}{ccc}
\hline Treatments & $\begin{array}{c}\text { Seedling } \\
\text { length }\end{array}$ & Vigour \\
\hline $\begin{array}{c}\text { hours } \\
\text { hoak seeds in water at } 21^{\circ} \mathrm{C} \text { for } 15\end{array}$ & $3.2^{\mathrm{a}}$ & $7.2^{\mathrm{a}}$ \\
Soaking seeds in water at $21^{\circ} \mathrm{C}+$ & $3.1^{\mathrm{a}}$ & $82.7^{\mathrm{b}}$ \\
oven heat & $2.9^{\mathrm{a}}$ & $180.6^{\mathrm{d}}$ \\
Hot water & $3.8^{\mathrm{b}}$ & $293.2^{\mathrm{e}}$ \\
Hot water + oven heat & $3.1^{\mathrm{a}}$ & $22.5^{\mathrm{a}}$ \\
Pre-chill seeds at $5^{\circ} \mathrm{C}$ for 24 hours & $3.2^{\mathrm{a}}$ & $157.5^{\mathrm{cd}}$ \\
Pre chilling+ oven heat & $4.1^{\mathrm{b}}$ & $154^{\mathrm{cd}}$ \\
Oven heat seeds at $70^{\circ} \mathrm{C}$ for 30 & & \\
minutes & $3.1^{\mathrm{a}}$ & $135.9^{\mathrm{c}}$ \\
Oven heat seeds at $80^{\circ} \mathrm{C}$ for 30 & & \\
minutes & $2.7^{\mathrm{a}}$ & $134.9^{\mathrm{c}}$ \\
Oven heat seeds at $90^{\circ} \mathrm{C}$ for 30 & $3.0^{\mathrm{a}}$ & $3.0^{\mathrm{a}}$ \\
minutes & Control
\end{tabular}

Means followed by the same Superscript along the column are not significantly different at $5 \%$ significant level by Duncan Multiple range test. All values in brackets were transformed by Arcsine transformation.

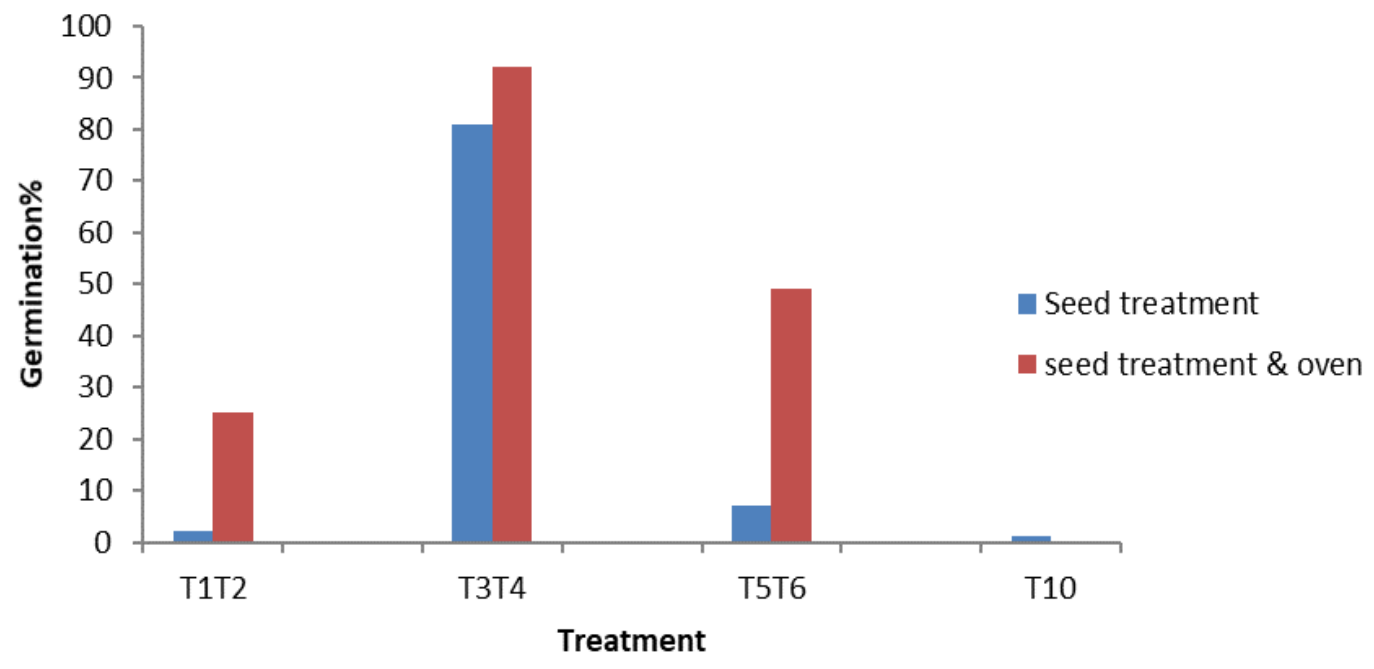

Fig.1: Germination relationship between seeds followed by oven treatments and non-oven treatments 


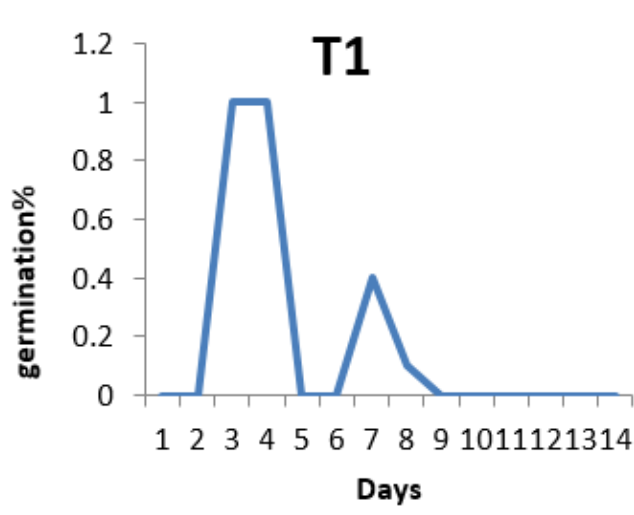

T3

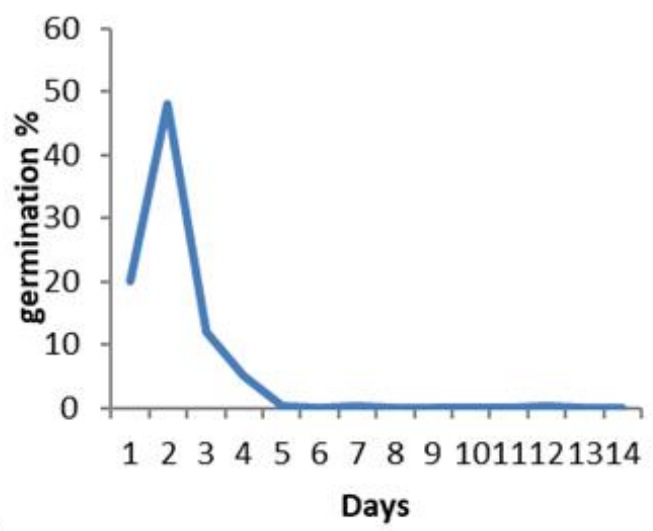

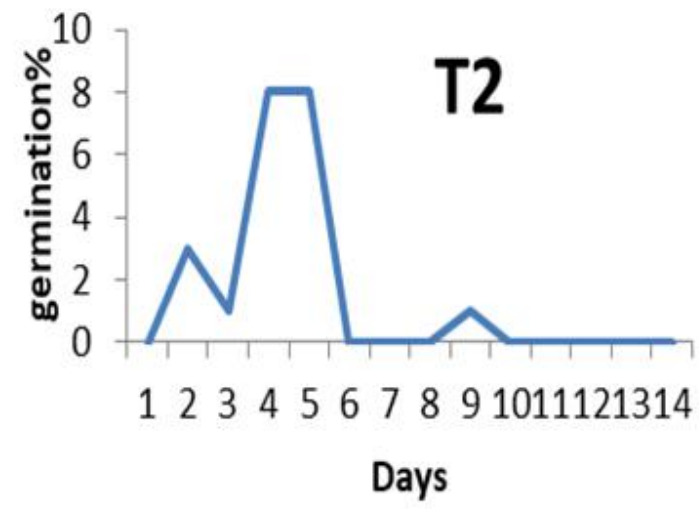

T4



Fig.2: Germination rate of jute mallow following various heat treatments (T1-T4)

T1: soak seeds in water at $21^{\circ} \mathrm{C}$ for 15 hours, $\mathrm{T} 2$ : Soak seeds in water at $21^{\circ} \mathrm{C}$ for 15 hours followed by oven heat, $\mathrm{T} 3$ : Hot water at $70^{\circ} \mathrm{C}$, T4: Hot water at $70^{\circ} \mathrm{CFollowed} \mathrm{by} \mathrm{oven} \mathrm{heat} \mathrm{at} 70^{\circ} \mathrm{C}$, T5: Pre chill at $5^{\circ} \mathrm{C}$ for 24 hours, T6: Pre-chill at $5^{\circ} \mathrm{C}$ for 24 hours followed by oven heat at $70^{\circ} \mathrm{C}, \mathrm{T} 10$ : Control).
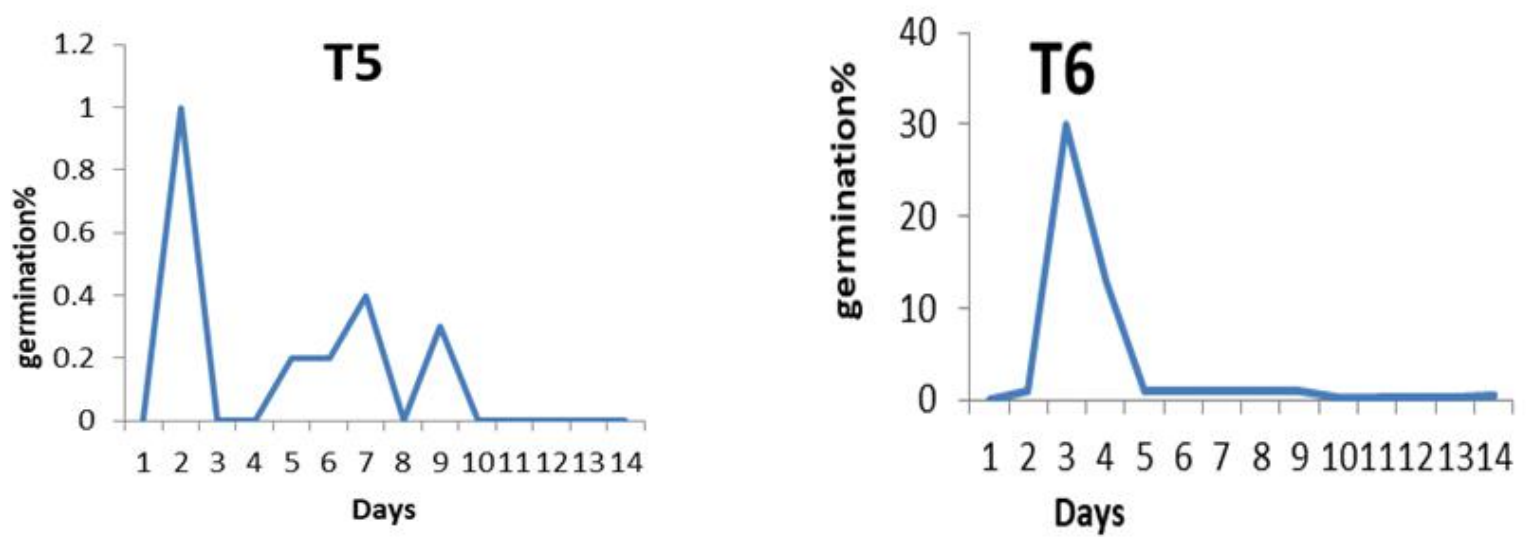

Fig.3: Germination rate of jute mallow following various heat treatments (T5-T6) 
(T1: soak seeds in water at $21^{\circ} \mathrm{C}$ for 15 hours, $\mathrm{T} 2$ : Soak seeds in water at $21^{\circ} \mathrm{C}$ for 15 hours followed by oven heat, T3: Hot water at $70^{\circ} \mathrm{C}, \mathrm{T} 4$ : Hot water at $70^{\circ} \mathrm{C}$ followed by oven heat at $70^{\circ} \mathrm{C}$, T5: Pre chill at $5^{\circ} \mathrm{C}$ for 24 hours, T6: Pre chill at $5^{\circ} \mathrm{C}$ for 24 hours followed by oven heat at $70^{\circ} \mathrm{C}$ )
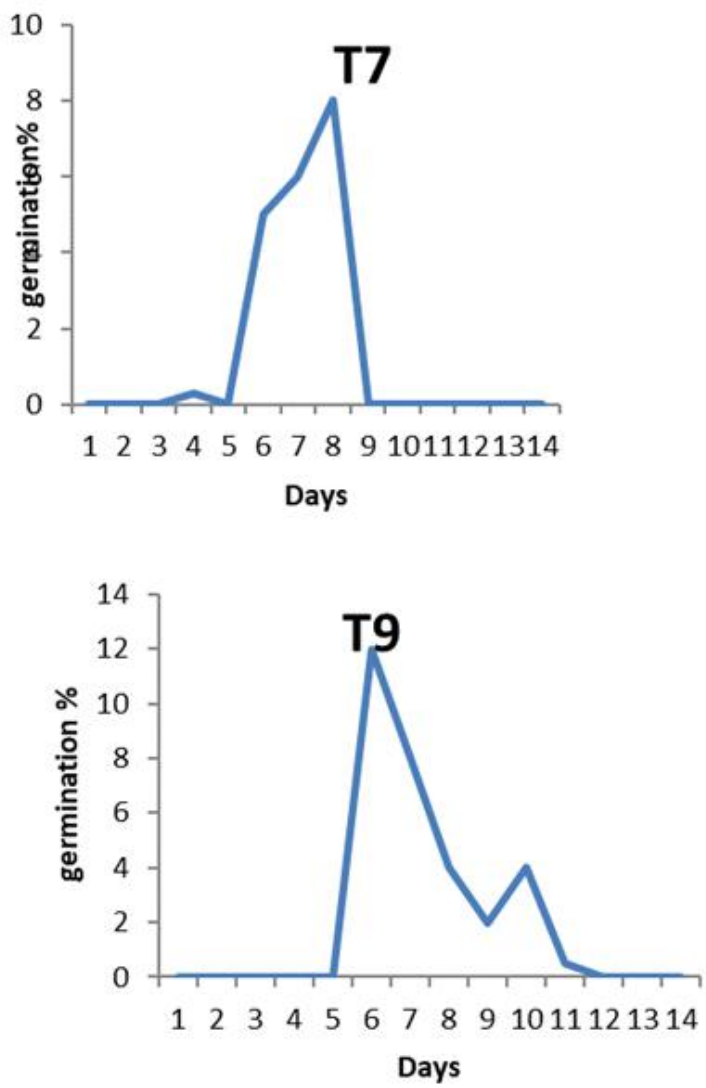

T8

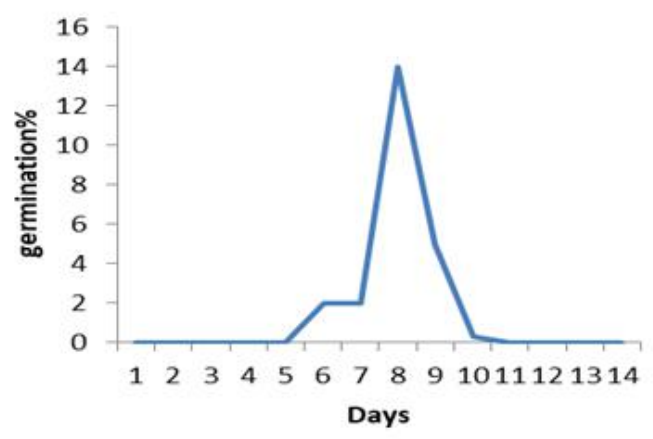

T10

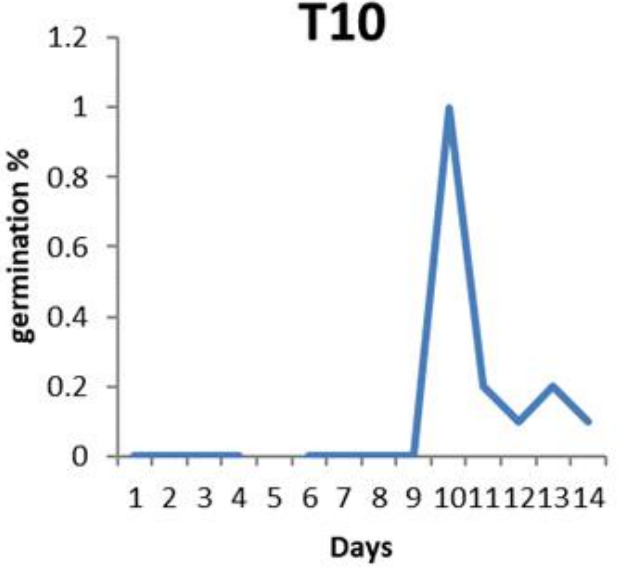

Fig.4: Germination rate of jute mallow following various heat treatments (T7-T10)

(T7: oven heat at $70^{\circ} \mathrm{C}, \mathrm{T} 8$ : oven heat at $80^{\circ} \mathrm{C}, \mathrm{T} 9$ : oven heat at $90^{\circ} \mathrm{C}, \mathrm{T} 10$ : Control)

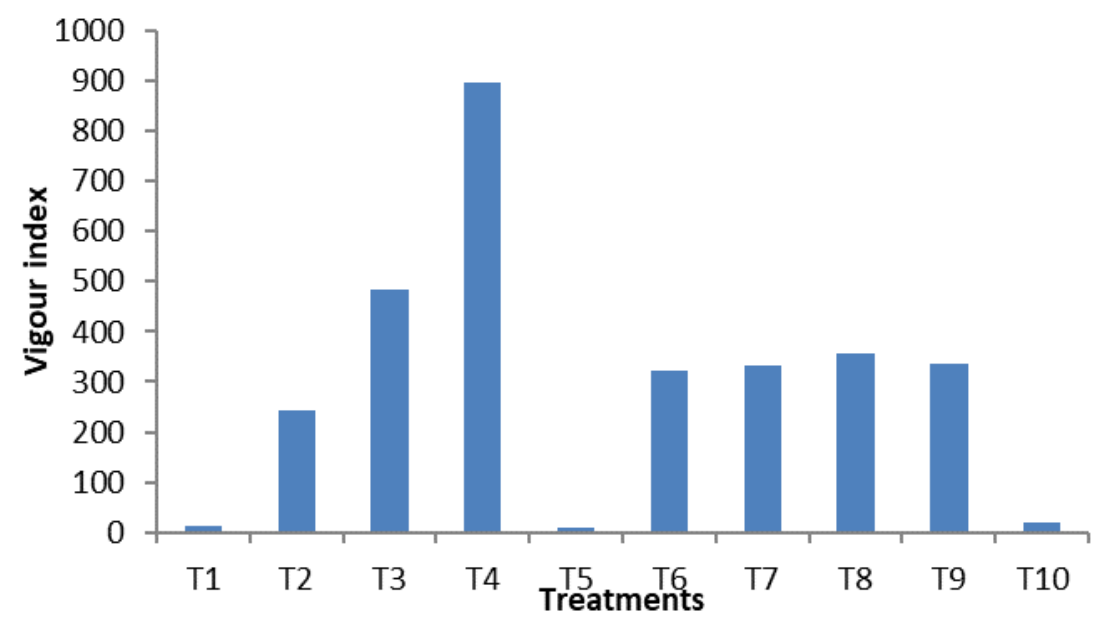

Fig.5: Effect of treatments on seedling vigor of emerged jute mallow seedlings 
T1: soak seeds in water at $21^{\circ} \mathrm{C}$ for 15 hours, $\mathrm{T} 2$ : Soak seeds in water $21^{\circ} \mathrm{C}$ for 15 hours followed by oven heat, T3: Hot water at $70^{\circ} \mathrm{C}, \mathrm{T} 4$ : Hot water at $70^{\circ} \mathrm{C}$ followed by oven heat at $70^{\circ} \mathrm{C}, \mathrm{T} 5$ : Pre chill at $5^{\circ} \mathrm{C}$ for 24 hours, T6: Pre chill at $5^{\circ} \mathrm{C}$ for 24 hours followed by oven heat at $70^{\circ} \mathrm{C}, \mathrm{T} 7$ : Oven heat at $70^{\circ} \mathrm{C}, \mathrm{T} 8$ : Oven heat at $80^{\circ} \mathrm{C}$, T9: Oven heat at $90^{\circ} \mathrm{C}, \mathrm{T} 10$ : Control)

\section{DISCUSSION}

\section{Health Status and Contributing Factors of Farmer Saved Seeds}

African indigenous vegetables are usually cultivated with other crops where the same plot is divided into sub plots and different crops are cultivated in each subplot; this agrees with (Maseko et al., 2018) who reported that African leafy vegetables are cultivated under a mixed cropping system. Farmers with a variety of crops are able to make sales every time compared to farmers who grow single crops because a crop is always available for sale notwithstanding, it also comes along with its challenges. It is however easy for pest and diseases to spread on such farms, especially when crops from the same family are found on the subplots. Pest easily migrate from one crop to another. The presence of fungi on the seed but not within the seed indicated that the seeds may have been kept with other contaminated seeds during storage. Seeds may also have been contaminated during the extraction process or through harvesting equipment or even via storage environments as seeds were not certified. Fungus is usually associated with stored grains and legumes; it also grows well where there is water (moist) and temperature interaction. Fungal infestation of seed coat decreased viability of seeds causing abnormal seedlings.

However, methods of sterilization such as hot water, natural compounds, commercial bleach and ethylene are able to get rid of the seed's infestation. Farmers are able to eradicate the fungal contamination on the seed coat of jute mallow unconsciously during the period of breaking dormancy by steeping the seeds in hot water (Selcuk et al., 2008). The seed is thus sterilized while dormancy is being broken and this reduces the risk of disease infestation in jute mallow. Disease causing bacteria present on the seed coat showed that the farmer saved-seeds did not go through any standard check, therefore, there is potential yield loss as a result of disease infestation in the life of the plant.

Efficient and Effective Methods of Breaking Dormancy on Germination and Seedling Vigor of Jute Mallow

ISSN: $2456-1878$

https://dx.doi.org/10.22161/ijeab.56.29
Hot water caused thermal shock to the embryo or leaching of inhibitors to enhance germination, however the embryo may be destroyed as a result of prolong contact with high temperatures which is consistent with (Velempini et al., 2003) who reported that, longer soaking times result in drastic reduction in germination.

Treatments included dipping jute mallow seeds into hot water when it starts to bubble and this caused germination. Based on the observations, the effect of temperature treatments on germination and seedling emergence followed similar trend with seeds dipped into hot water at $70^{\circ} \mathrm{C}$ followed by oven heat at $70^{\circ} \mathrm{C}$ for 30 minutes showing the highest germination and seedling emergence. Seed dormancy in jute mallow is physical dormancy and is usually as a result of hard seed covering which prevent water from entering into the seed (Abukutsa-Onyango, 2005). The hot water thus scarified the seed coat and caused water imbibition hence facilitating germination and emergence. The high temperature also provided good medium for enzymes to catalyze the breakdown of seed coat and this allowed the water imbibition and gaseous exchange thereby enhancing germination and emergence.

Exposing seeds to oven heat at $70^{\circ} \mathrm{C}$ showed moderate seedling emergence, which increased with temperature at $80^{\circ} \mathrm{C}$. Dry heat produced may have cracked the hard seed coat making it permeable to water when moistened similar to method of breaking dormancy in some Acacia tree species (Walters et al., 2004). This explains why seeds in the wild readily germinate and produce seedlings during the rains on farms that were burned during land preparation (Denton et al., 2013). No significant increase in seedling emergence and germination were obtained when oven heat temperature was increased from $80^{\circ} \mathrm{C}$ to $90^{\circ} \mathrm{C}$ for 30 minutes. This could be as a result of embryo damage due to the excessive high temperature and this observation was contrary to Denton et al., (2013) who reported that irrespective of how long jute mallow seeds were subjected to bush fire, there were seedling emergence on the field after the first rain. The difference in germination and emergence when temperature increased from $80^{\circ} \mathrm{C}$ to $90^{\circ} \mathrm{C}$ may also be as a result of embryo damage due to the prolong exposure of the seed to dry heat causing seeds to dehydrate hence increased mortality.

The control treatment and seeds soaked in water at $21^{\circ} \mathrm{C}$ for 15 hours did not enhance germination at all. The seed coat could not be modified to imbibe water for germination to occur due to physical dormancy. Pre chilling 
seeds at $5^{\circ} \mathrm{C}$ for 24 hours resulted in poor germination and emergence which agrees with (Nkomo et al., 2009b) who reported that there was no germination for seeds that were pre-chilled for one(1) day. However, seeds that were prechilled with oven heat combination showed significant difference in germination. This finding agrees with (Nkomo \& Kambizi, 2009b) who reported that germination occurred when seeds were exposed to temperature of $35^{\circ} \mathrm{C}$ and above.

Hot water followed by oven heat treatment showed high seedling vigor for both germination and emergence indicating that, hot water and dry heat enhanced germination, emergence and seedling length. Though the seeds had high viability, the treatments for breaking dormancy favored the plant establishment. The term "seed vigor" has a concept associated with aspects of seed performance which include rate and uniformity of seed germination, seedling growth and emergence. Seeds soaked in water at $21^{\circ} \mathrm{C}$ (T1), seeds soaked in water followed with oven heat (T2) and control (T10) produced low seed vigor. This was as a result of poor seedling performance in terms of height and germination which agrees with the International rules for seed testing's explanation of seedling vigor as the total properties that determines the activity and acceptable germination performance of seed (ISTA, 2015).

Germination rate is a necessary parameter in crop establishment on the field. The effect of treatments on the seed varied significantly, seeds dipped into hot water only (T3) and seeds dipped into hot water followed by oven treatments (T4) were the only treatments that started germination from the first day of germination count. This is consistent with other findings that hot water treatments enhance germination (Maina et al., 2011). Germination started on day one and increased by day two but the rate of germination decreased in the subsequent days. About $85 \%$ of the total seeds' germinations occurred from day one (1) to two (2) while the remaining treatments started germinating between day two (2) and fourteen (14). The trends of germination rates of the various treatments indicated their effectiveness in breaking dormancy with the control taking the longest time to germinate. A low germination of $2.5 \%$ is an indication of the importance of treating seeds of jute mallow prior to planting.

Also soaking seeds in water at $21^{\circ} \mathrm{C}$ alone is equally not very effective. Maximum germination rate for treatment (6 and 1) occurred on day three, treatment (2) was on day four, treatment (7and 8) was on day eight, treatment (9) was on day six and treatment (10) started germinating on day ISSN: 2456-1878

https://dx.doi.org/10.22161/ijeab.56.29 fourteen. This revealed that, though the other treatment enhanced germination at some point, there was delay in germination which makes the treatment method ineffective for breaking dormancy.

Treatment 10 which was the control had its maximum germination on day fourteen with germination percentage of $2.5 \%$ revealing that jute mallow seeds will not germinate at all or have poor germination and seedling vigor when it is not treated before sowing. Soaking seeds in ordinary water at room temperature (T1) resulted in 5\% germination and was not an effective method of breaking dormancy. It agrees with the report by (Maina et al., 2011) that soaking jute mallow seeds in ordinary water will not break dormancy.

\section{CONCLUSION}

The quality of farmer saved-seeds in terms of purity and viability is adequate as it was above $80 \%$ for both $87 \%$ and $92 \%$ respectively. For seed health quality, no seed borne pathogen were observed. Hot water followed by oven heat treatment can be adopted on large scale production while small scale producers can employ hot water treatment for uniform growth and development.

The best treatment for breaking dormancy in jute mallow from the study was dipping seeds in hot water treatment at $70^{\circ} \mathrm{C}$ for five (5) minutes followed by oven heat at temperature of $70^{\circ} \mathrm{C}$ for thirty (30) minutes as it gave the highest seedling germination, emergence and vigour. Hot water treatment and hot water combination with oven heat enhanced germination and good germination rate.

Hot water followed by oven heat treatment should be used by large scale producers while small scale producers use only hot water treatment.

\section{ACKNOWLEDGEMENTS}

This work was funded by the DAAD-In Region Scholarship Programme - West Africa Centre for Crop Improvement (WACCI), 2017. The authors would like to sincerely thank the editor and anonymous reviewers for their helpful and insightful comments and suggestions that have resulted in a much-improved version of this manuscript.

\section{DISCLOSURE}


The authors declare that there are no financial supports or relationship that may pose conflicts of interest.

\section{REFERENCES}

[1] Adebooye, O., Ajayi, S., Baidu-Forson, J., \& Opabode, J. (2005). Seed constraint to cultivation and productivity of African indigenous leaf vegetables. African Journal of Biotechnology, 4(13).

[2] Akinola, J., Larbi, A., Farinu, G., \& Odunsi, A. (2000). Seed treatment methods and duration effects on germination of wild sunflower. Experimental Agriculture, 36(1), 63-69.

[3] Baskin, C. C. (2003). Breaking physical dormancy in seedsfocussing on the lens. New Phytologist, 158(2), 229-232.

[4] Copeland, L. O., \& McDonald, M. B. (2001). Seed vigor and vigor testing Principles of Seed Science and Technology (pp. 165-191): Springer.

[5] Denton, O., Oyekale, K., Nwangburuka, C., Daramola, D., Adeyeye, J., \& Olukayode, O. (2013). Influence of high dry heat temperature on seed germination, seedling emergence and seedling vigour of three cultivars of Corchorus olitorius seeds. American Journal of Research Communication, 1(5), 98-114.

[6] Emongor, V., Mathowa, T., \& Kabelo, S. (2004). Acid and ethephon on the germination of corchorus (Corchorus Widens) seed. Journal of Agronomy, 3(3), 196-200.

[7] Etwire, P. M., Atokple, I. D., Buah, S. S., Abdulai, A. L., Karikari, A. S., \& Asungre, P. (2013). Analysis of the seed system in Ghana. International Journal of Advance Agricultural Research, 1(1), 7-13.

[8] Geneve, R. L. (2005). Vigor testing in flower seeds. Flower seeds: biology and technology, CAB, Wallingford, UK, 311332.

[9] Ilori, T., Adejumo, A., Akinyele, O., \& Oladimeji, S. (2016). Some Physical Properties of Corchorus Olitorius Seed as Function of Moisture Content. European Journal of Academic Essays, 3(4), P174-177.

[10] Lewu, F., \& Mavengahama, S. (2010). Wild vegetables in Northern KwaZulu Natal, South Africa: Current status of production and research needs. Scientific Research and Essays, 5(20), 3044-3048.

[11] Loumerem, M., \& Alercia, A. (2016). Descriptors for jute (Corchorus olitorius L.). Genetic resources and crop evolution, 63(7), 1103-1111.

[12] Maina, F. N., Muasya, R. M., \& Gohole, L. S. (2011). Dormancy breaking in jute Mallow (Corchorus olitorius) seeds. Seed Technology, 147-154.

[13] Mathowa, T., Madisa, M., Moshoeshoe, C., Mojeremane, W., \& Mpofu, C. (2014). Effect of different growing media on the growth and yield of jute mallow (Corchorus olitorius L.). International Journal of Research Studies in Biosciences, 2(11), 153-163.
[14] Ndinya, C., \& Ndinya, C. (2005). Seed production and supply system of three African Leafy Vegetables in Kakamega District. Paper presented at the Proceedings of the third Horticulture Workshop on Sustainable Horticultural production in the Tropics. Maseno University, Masono.

[15] Ndlovu, J., \& Afolayan, A. (2008). Nutritional analysis of the South African wild vegetable Corchorus olitorius L. Asian J Plant Sci, 7(6), 615-618.

[16] Nkomo, M., \& Kambizi, L. (2009a). Effects of pre-chilling and temperature on seed germination of Corchorus olitorius L.(Tiliaceae)(Jews Mallow), a wild leafy vegetable. African Journal of Biotechnology, 8(6), 1078-1081.

[17] Nkomo, M., \& Kambizi, L. (2009b). Length Research Paper Effects of pre-chilling and temperature on seed germination of Corchorus olitorius L.(Tiliaceae)(Jew's Mallow), a wild leafy vegetable. African Journal of Biotechnology, 8(6).

[18] Nyadanu, D., Amoah, R. A., Kwarteng, A., Akromah, R., Aboagye, L., Adu-Dapaah, H., . . . Tsama, A. (2017). Domestication of jute mallow (Corchorus olitorius L.): ethnobotany, production constraints and phenomics of local cultivars in Ghana. Genetic resources and crop evolution, 64(6), 1313-1329.

[19] Okeno, J., \& Chebet, D. (2003). PW Mathenge Status of indigenous vegetables in Kenya. Acta Hort, 621, 95-100.

[20] Olabode, O., \& Sangodele, A. (2014). Effect of preemergence herbicides on the growth, yield and drawing quality of jute mallow (corchorusolitorius).

[21] Olayemi, R. A., \& Rahman, A. (2013). Thermal properties of some selected nigerian soups. Agricultural Sciences, 4(05), 96.

[22] Oyedele, D., Asonugho, C., \& Awotoye, O. (2006). Heavy metals in soil and accumulation by edible vegetables after phosphate fertilizer application. Electron J Environ Agric Food Chem, 5(4), 1446-1453.

[23] Palada, M., \& Chang, L. (2003). Suggested cultural practices for jute mallow. International Cooperator Guide, 2(14), 1-4.

[24] Palada, M. C., \& Crossman, S. M. (1999). Evaluation of tropical leaf vegetables in the Virgin Islands. Perspectives on new crops and new uses. ASHS Press, Alexandria, VA, 388393.

[25] Parakh, A., \& Kak, S. (2009). Online data storage using implicit security. Information Sciences, 179(19), 3323-3331.

[26] Rahman, S., \& Khan, M. (2010). Integrated management approach for control of the pest complex of olitorius jute, Corchorus olitorius L. Journal of plant protection research, 50(3), 340-346.

[27] Schippers, R. (2006). Traditional vegetables in Africa. Paper presented at the Proc. Int. Symp. on the Nutritional value and Water Use of Indigenous Crops for Improved Livelihoods.

[28] Schippers, R., Maundu, P., Imbuni, M., \& Obiero, H. (2002a). How to grow and Use Jew's mallow. Horticultural Development Services, Baarn, The Netherlands, 10. 
[29] Schippers, R., Maundu, P., Imbuni, M., \& Obiero, H. (2002b). How to grow and Use Spider Plant. Horticultural Development Services, Baarn, The Netherlands, 10.

[30] Selcuk, M., Oksuz, L., \& Basaran, P. (2008). Decontamination of grains and legumes infected with Aspergillus spp. and Penicillum spp. by cold plasma treatment. Bioresource technology, 99(11), 5104-5109.

[31] Solorzano, C., \& Malvick, D. (2011). Effects of fungicide seed treatments on germination, population, and yield of maize grown from seed infected with fungal pathogens. Field Crops Research, 122(3), 173-178.

[32] Tareq, M., Khan, M., Mollah, M., Hasan, M., \& Alam, M. (2015). Effect of storage environment on jute seed qualities. Bangladesh J. Env. Sci, 29, 45-48.

[33] Van der Westhuizen, L., Shephard, G., Rheeder, J., Burger, H.-M., Gelderblom, W., Wild, C., \& Gong, Y. (2010). Simple intervention method to reduce fumonisin exposure in a subsistence maize-farming community in South Africa. Food Additives and Contaminants, 27(11), 1582-1588.

[34] van Gastel, T. J., Gregg, B. R., \& Asiedu, E. (2002). Seed quality control in developing countries. Journal of New Seeds, 4(1-2), 117-130.
[35] Velempini, P., Riddoch, I., \& Batisani, N. (2003). Seed treatments for enhancing germination of wild okra (Corchorus olitorius). Experimental Agriculture, 39(4), 441-447.

[36] Vijayakumar, H., Vijayakumar, A., Srimathi, P., Somasundaram, G., Prasad, S., Natarajan, S., . . Vishwanath, K. (2019). Correlation among physiological and histological changes in soybean seeds during storage. Journal of Environmental Biology, 40(2), 217-225.

[37] Vorster, H., Jansen van Rensburg, W., Van Zijl, J., \& Van Den Heever, E. (2002). Germplasm management of African leafy vegetables for the nutritional and food security needs of vulnerable groups in South Africa. Progress Report. ARCVOPI, Pretoria, South Africa, 130.

[38] Wahab, O. D. (2011). Effect of Dry Heat Temperature on Seed Germination and Seedling Emergence of three Cultivars of Corchorus olitorious Seeds.

[39] Walters, M., Midgley, J. J., \& Somers, M. J. (2004). Effects of fire and fire intensity on the germination and establishment of Acacia karroo, Acacia nilotica, Acacia luederitzii and Dichrostachys cinerea in the field. BMC ecology, 4(1), 3.

\section{Appendix}

\section{Anova table for percentage germination}

Source of variation

Rep stratum

d.f.

S.s. 3

$123.28 \quad 41.09$

Treatment

9

23320.62

$695.48 \quad 25.76$

Residual

27

Total m.s.

v.r.

F pr.

\section{Anova table for germination vigor}

$\begin{array}{lllllll}\text { Source of variation } & \text { d.f. } & \text { s.s. } & \text { m.s. } & \text { v.r. } & \text { F pr. } \\ \text { Rep stratum } & 3 & 3787.3 & 1262.4 & 2.89 & & \\ \text { Treatment } & & 9 & 286451.0 & 31827.972 .93 & <.001 & \\ \text { Residual } & 27 & & 11782.5 & 436.4 & & \end{array}$

\section{Anova table for seedling emergence}

\begin{tabular}{|c|c|c|c|c|c|c|}
\hline Source of variation & & d.f. & s.s. & m.s. & v.r. & F pr. \\
\hline Rep stratum & & & 0.012729 & 0.006365 & 1.93 & 0.173 \\
\hline Treatment & & & 2.919484 & 0.324387 & 98.61 & $<0.001$ \\
\hline Residual & & 0.059211 & & & & \\
\hline Total & 29 & 2.991424 & & & & \\
\hline
\end{tabular}

